\title{
Gamma Globulins Adsorption on Carbofunctional Polysiloxane Microspheres
}

\author{
Urszula Mizerska $^{1} \cdot$ Witold Fortuniak $^{1} \cdot$ Piotr Pospiech $^{1} \cdot$ Julian Chojnowski $^{1}$ \\ Stanislaw Slomkowski ${ }^{1}$
}

Received: 29 January 2015/Accepted: 14 March 2015/Published online: 22 March 2015

(C) The Author(s) 2015. This article is published with open access at Springerlink.com

\begin{abstract}
Polysiloxane microspheres containing a large number of silanol groups were functionalized by reactions of these groups with organic alkoxy or chlorosilanes having chloro, amine or imidazole functions in their organic parts. The obtained imidazole groups on the microspheres were ionized by the reaction with $n$-octyl iodide and with methyl iodide while the chloro functions were used for quaternization of a tertiary amine. Adsorption of gamma globulins on these functionalized microspheres was studied in aqueous suspension at $\mathrm{pH}$ 5.2, 7.4 and 9.2. Hydrophilichydrophobic properties of these microspheres were examined by measuring adsorption of a hydrophobic dye, Rose Bengal. The functionalized microspheres showed higher adsorption of globulins and higher hydrophobicity than the not functionalized ones rich in silanol groups. In the case of microspheres with ionic functional groups the electrostatic forces also contribute to attractive interactions between proteins and microspheres.
\end{abstract}

Keywords Protein adsorption - Polysiloxane microspheres · Hydrophilic-hydrophobic properties . Functional microspheres

This paper is dedicated to Professor Eberhard Neuse in recognition of his great and valuable contribution to polymer and medicinal chemistry.

Julian Chojnowski

jchojnow@cbmm.lodz.pl

1 Center of Molecular and Macromolecular Studies of Polish Academy of Sciences, 112 Sienkiewicza, 90-363 Lodz, Poland

\section{Introduction}

Proteins show a large affinity to surfaces of various silicone materials. Adsorption of proteins on these surfaces occurs instantly whenever silicones are exposed to biological medium $[1,2]$. This phenomenon is a very common one and has a great impact on biomedical and biotechnical applications of silicone materials [2-4]. Many undesired events such as blood coagulation, thrombosis, immune reactions leading to diseases are caused by protein adsorption $[2,5]$. On the other hand, the protein adsorption is used to bioactivate synthetic materials. The ability of surfaces to adsorb proteins is important in the case of materials used in tissue engineering [6], biosensors [7], drug carriers [8, 9], adsorbents [2], protein chromatography [10] and biocatalysts $[11,12]$. Controlling of the affinity of proteins to surface of materials is a challenge. It is generally accepted that the adsorption of proteins on non-polar surfaces is mostly controlled by hydrophobic-hydrophilic properties of the surface $[4,5]$. These properties may be tuned by functionalization of surfaces. Many studies on functionalization of polysiloxanes was devoted to induce hydrophilicity of their surfaces $[1,9,13-15]$. Very little is known about the nature of protein interactions with colloidal polysiloxane particles, in spite that some studies in this area have been conducted [9, 16-18]. Even less attention was paid to affinity of proteins to polysiloxane particles with ionic groups. However, it was noticed that presence of ionic groups on surface of polysiloxane may lead to important contribution of electrostatic interaction to the driving force of protein adsorption [16, 19].

Recently, in our laboratory there was developed a process suitable for synthesis of polysiloxane microspheres containing a large number of silanol groups [20]. Hydroxyl bonded silicon atoms constituted about half of the total 
number of silicon atoms in these particles. We found that these particles are highly hydrophilic and do not adsorb a hydrophobic dye Rose Bengal from its aqueous solution [21]. We noticed also that adsorption of gamma globulins on these microspheres was very low. The possibility of tuning hydrophilic-hydrophobic properties of microspheres with silanol groups by their partial trimethylsilylation or by the introduction of izopropoxyl groups to microsphere precursor was demonstrated [21]. During studies described in this paper we wanted to learn how replacement of silanol groups by ionic and electrically neutral carbon functional ones affects adsorption of proteins. For this purpose the groups with imidazole function were introduced into the microspheres. Later, these groups were transformed to imidazolium ones in reaction with alkyl iodides. During our studies we investigated also microspheres bearing amine groups and their derivatives with quaternary ammonium groups were studied. Gamma globulins from human blood were used as model proteins for adsorption studies. These proteins were selected for the studies because they are well defined and show a high affinity to surfaces of many materials [22-25]. They are often used in studies of protein adsorption [22, 24-26]. Gamma globulins are present in biological fluids where they play important physiological roles [27].

\section{Experimental Section}

\subsection{Materials}

3-Aminopropyltriethoxysilane-ABCR, $97 \%$ of declared purity; 3-chloropropylmethyldichlorosilane,-ABCR, $97 \%$; dichloromethylsilane-Aldrich; $97 \% ; \quad N$-allylimidazole $97 \%$; n-octyldimethylamine-Aldrich, $95 \%$; triethylamine -POCH Gliwice, p.a.; 1-iodooctane-Aldrich, $98 \%$; methyl iodide—Sigma-Aldrich, $99 \%$; Bradford reagent—for $1-1.4000 \mathrm{mg} / \mathrm{mL}$ protein-Sigma-Aldrich; Rose BengalAldrich, $\geq 90 \%$. These chemicals were used without additional purification, but their purity was confirmed by gas chromatography.

\subsection{Methods}

${ }^{29}$ Si MAS NMR spectra were recorded with a DSX 400 Bruker spectrometer working at $59.627 \mathrm{MHz}$. The spectra were acquired with cross-polarization, applying $90 \mu \mathrm{s}$ pulses, $6 \mathrm{~s}$ pulse delay, and $3 \mathrm{~ms}$ contact time, with samples in $4.0 \mathrm{~mm}$ zirconia rotors spinning at $8 \mathrm{kHz}$. The peak positions were referenced to the signal of $\mathrm{Q}_{8} \mathrm{M}_{8}$. In order to raise the precision of the analysis of the chemical composition of microspheres, a comparable measurement in a single pulse excitation (SPE) mode was performed for a chosen sample, which allowed to introduce corrections to the data obtained from the cross-polarization experiments. The SPE spectra were recorded with $\pi / 2$ pulse equal to $5 \mu \mathrm{s}$ and relaxation delay of $100 \mathrm{~s}$.

${ }^{13} \mathrm{C}$ MAS NMR spectra were taken with the DSX 400 Bruker spectrometer working at $100.61 \mathrm{MHz}$ using 4-mm $\mathrm{ZrO}_{2}$ rotors, spinning rate $8 \mathrm{kHz}$, contact time $2 \mathrm{~ms}$ and repetition delay $2 \mathrm{~s}$. The acquisition was collected with SPINAL 16 decoupling sequence.

SEC measurements were performed in toluene using a Knauer Advanced Scientific instrument with a differential refractive index detector Wyatt miniDawn Treos (MALS).

SEM images were taken with the Jeol JSH 5500 LV microscope in high vacuum mode at the accelerated voltage of $10 \mathrm{kV}$. Samples were coated with a fine gold layer (about $20 \mu \mathrm{m}$ thick) using the ion coating JEOL JFC 1200 apparatus.

\subsection{Synthesis}

The native silanol containing microspheres were prepared as described elsewhere [20]. They contain $6.3 \mathrm{~mol} / \mathrm{g} \mathrm{SiOH}$ groups and have average diameter $15.5 \mu \mathrm{m}$ with standard deviation $7.24 \mu \mathrm{m}$.

Imidazole containing microspheres were obtained in result of the reaction of $N$-[3-(dimethylchlorosilyl)propyl]imidazole hydrochloride with silanol groups on the native microspheres. The synthesis of the imidazole containing silane and its reaction with silanol were carried out in similar ways to those described in Ref. [28].

The imidazole groups in microspheres were further modified to generate imidazolium iodide functionalized particles. For this purpose a sample of imidazole containing microspheres $\left(4.54 \mathrm{~g}, 1.46 \times 10^{-3} \mathrm{~mol} / \mathrm{g}\right.$ of imidazole $)$ were dispersed in the solution of $n$-octyl iodide $39.6 \mathrm{~g}(0.165 \mathrm{~mol})$ in $25 \mathrm{~mL}$ of DMF. The suspension was stirred at $45^{\circ} \mathrm{C}$ for $140 \mathrm{~h}$. Microspheres were separated, washed 4 times with $50 \mathrm{~mL}$ portions of toluene and then three times with $50 \mathrm{~mL}$ portions of methanol. After drying on a vacuum line they were subjected to instrumental and elemental analysis. Elemental analysis showed: $\mathrm{C}-28 \%$; $\mathrm{H}-65.67 \%$; N-2.2 \%. Microspheres containing 3-N(N-methylimidazolio)propyl groups were prepared in a similar way.

$n$-Octyldimethylammoniopropyl chloride containing microspheres were synthesized from 3-chloropropyl functionalized microspheres: 3-chloropropyl groups were introduced to the silanol containing microspheres. These microspheres $\left(7.34 \mathrm{~g}\right.$ containing $6.3 \times 10^{-3} \mathrm{~mol} / \mathrm{g}$ of $\mathrm{SiOH})$ were dispersed in the mixture of $35 \mathrm{~mL}$ of toluene and $30 \mathrm{~mL}$ of triethylamine. The suspension was stirred and the solution of 3-chloropropylmethyldichlorosilane $(18 \mathrm{~g}, 0.094 \mathrm{~mol})$ in $15 \mathrm{~mL}$ of dry toluene was introduced under nitrogen during $1.5 \mathrm{~h}$. After additional $6 \mathrm{~h}$ of stirring 
the mixture of $60 \mathrm{~mL}$ of ethanol and $20 \mathrm{~mL}$ of water was added. The microspheres were isolated and rinsed many times with toluene. Then their suspension in toluene was washed three times with $50 \mathrm{~mL}$ of distilled water to remove traces of $\mathrm{HCl}$ and was dried on a vacuum line. Elemental analysis gave: $\mathrm{C}-27.53 \%$; $\mathrm{H}-6.52 \%$; $\mathrm{Cl}-$ $6.07 \%$, which corresponded to $1.71 \times 10^{-3} \mathrm{~mol} / \mathrm{g}$ of chloropropyl groups. These microspheres were further used to obtain 3-n-octyldimethylammoniopropyl chloride groups. 3-chloropropyl containing microspheres $(1.84 \mathrm{~g})$ were heated at $55{ }^{\circ} \mathrm{C}$ for $170 \mathrm{~h}$ with of $n$-octyldimethylamine $(11.2 \mathrm{~g}, 0.071 \mathrm{~mol})$ in $10 \mathrm{~mL}$ of dimethylformamide. Microspheres were isolated, washed 6 times with portions of $10 \mathrm{~mL}$ of methanol, dried on a vacuum line and subjected to analyses. Elemental analysis showed $\mathrm{C}-25,26 \%$; $\mathrm{H}-$ $6,91 \% ; \mathrm{N}-0.58 \%$.

3-aminopropyl groups containing microspheres were synthesized as described in Ref. [20].

\subsection{Evaluation of Protein Adsorption}

Fresh phosphate buffered saline solutions (PBS) with $\mathrm{pH}$ 7.4 were used for preparation of two series of gamma globulin solutions with protein concentration ranging from 152.7 to $916.2 \mu \mathrm{g} / \mathrm{mL}$ and from 169.9 to $1017.6 \mu \mathrm{g} / \mathrm{mL}$. Portions of $100 \mathrm{mg}$ of studied microspheres were placed into vials. Thereafter the solutions of gamma globulins with known concentrations were introduced to the vials. Vials were gently shaken for $24 \mathrm{~h}$ at $20^{\circ} \mathrm{C}$. Series of solutions of gamma globulins with identical protein concentrations were prepared and used as standards. All these solutions including standards, were gently shaken at $25{ }^{\circ} \mathrm{C}$ for the period of $20 \mathrm{~h}$. Then microspheres were separated by centrifuging. Supernatant $(0.1 \mathrm{~mL})$ was added to $3 \mathrm{~mL}$ of the Bradford reagent and after $10 \mathrm{~min}$ the UV spectrum of the solution was registered. The mixture of $3 \mathrm{~mL}$ of the Bradford reagent with $0.1 \mathrm{~mL}$ of the PBS solution was used as blank. Separately the spectrum of the standard protein solution was taken and the difference of the absorbance at $595 \mathrm{~nm}$ was used for the evaluation of the amount of adsorbed protein. In a similar way adsorption was evaluated for the globulins solution at $\mathrm{pH} 5.2$ and 9.2. A phosphate and carbonate buffers were used to adjust $\mathrm{pH}$ to 5.2 and 9.2 , respectively.

\subsection{Studies of Hydrophilic-Hydrophobic Properties of Microspheres}

Hydrophobicity of the surface of investigated particles was determined by the method described earlier, using a hydrophobic dye (Rose Bengal) as a probe [31-33]. A sample of Rose Bengal was dissolved in deionized water to obtained the stock solution $\left(9.67 \times 10^{-4} \mathrm{~g} / \mathrm{mL}\right)$. In a series of vials, each containing $2 \mathrm{~mL}$ of PBS buffer solution keeping $\mathrm{pH}$ at 7.4, samples of microspheres $(10-50 \mathrm{mg}$ ) were placed. A vial containing the solution without microspheres was used as a standard. After $30 \mathrm{~min}$, the solution of Rose Bengal was added to the vials to obtain suspensions of microspheres with dye concentration equal $20 \mu \mathrm{g} / \mathrm{mL}$. The suspensions were shaken at $250 \mathrm{rpm}$ at $20{ }^{\circ} \mathrm{C}$ for $4 \mathrm{~h}$. Then, microspheres were separated by centrifuging, supernatants were diluted and subjected to the UV absorbance measurement at $548.5 \mathrm{~nm}$. Then a series of $80 \mathrm{mg}$ of microspheres suspended in $2 \mathrm{~mL}$ of distilled water was prepared in vials. After shaking the vials for 30 min Rose Bengal was added to obtain its solutions having concentrations ranging $2-14 \mu \mathrm{g} / \mathrm{mL}$. The shaking $(450 \mathrm{rpm})$ was continued at room temperature $\left(23^{\circ} \mathrm{C}\right)$ for $3 \mathrm{~h}$. Then absorbance was measured at $549.5 \mathrm{~nm}$ and compared with the standard.

\section{Results and Discussions}

\subsection{Preparation of Functionalized Microspheres}

Silanol containing microspheres were synthesized by aqueous emulsion process of polyhydrosiloxane with grafted vinyltetramethyldisiloxane groups. Synthesis was carried out as it was described elsewhere [20]. The solidification of microspheres occurred by cross-linking of the polymer via hydrosilylation. Parallel to this reaction the hydrolysis of $\mathrm{SiH}$ producing silanol groups did occur and the $\mathrm{SiH}+\mathrm{SiOH}$ condensation enhanced cross-linking. All these three reactions proceeded in the emulsion and all were promoted by the $\operatorname{Pt}(0)$ Karstedt catalyst. Parameters characterizing the silanol containing microspheres are given in Table 1. Their ${ }^{29} \mathrm{Si}$ MAS NMR and ${ }^{13} \mathrm{C}$ MAS NMR spectra are shown in Figs. 1 and 2 respectively. These microspheres were subjected to reaction with carbon functional reactive silanes containing chlorosilane or alkoxysilane functions. Functionalization did occur during reaction of silanes having carbon functional groups with silanol groups of microspheres. Modifications were carried out in a toluene suspension of microspheres and were controlled by gas chromatography and ${ }^{13} \mathrm{C}$ MAS NMR spectroscopy (Fig. 2).

The quaternary ammonium groups were introduced into microspheres in a two step process (see Eq. 1). First, the microspheres were subjected to reaction with 3-chloropropylmethyldichlorosilane. This reaction charged the microspheres with 3-chloropropyl functions, which were further used for the quaternization of $n$-octyldimetylamine. Primary amine groups were introduced by reaction with 3-aminopropyltriethoxysilane according to Eq. $2 . \mathrm{N}$ alkylimidazole groups were introduced by the reaction of 
Table 1 Contents of functional groups in microspheres

\begin{tabular}{llllr}
\hline No & Functional group & Carbofunctional group ${ }^{\mathrm{a}}\left(\mathrm{mol} / \mathrm{g} \times 10^{3}\right)$ & $\mathrm{SiOH}^{\mathrm{b}}\left(\mathrm{mol} / \mathrm{g} \times 10^{3}\right)$ & $\mathrm{SiH}^{\mathrm{b}}\left(\mathrm{mol} / \mathrm{g} \times 10^{3}\right)$ \\
\hline 1 & $\mathrm{SiOH}($ native $)$ & - & 6.4 & 1.46 \\
2 & $\mathrm{Si}\left(\mathrm{CH}_{2}\right)_{3} \mathrm{NH}_{2}$ & 2.24 & 0.95 & 1.03 \\
3 & $\mathrm{Si}\left(\mathrm{CH}_{2}\right)_{3}-\mathrm{Im}$ & 1.46 & 2.00 & 0.28 \\
4 & $\mathrm{Si}\left(\mathrm{CH}_{2}\right)_{3}-\mathrm{ImOct}^{+} \mathrm{I}^{-}$ & 0.79 & 1.03 & 0.10 \\
5 & $\mathrm{Si}\left(\mathrm{CH}_{2}\right)_{3} \mathrm{NMe}_{2} \mathrm{Oct}^{+} \mathrm{Cl}^{-}$ & 0.41 & 0.69 & $<0.01$ \\
\hline
\end{tabular}

${ }^{a}$ Determined from elemental analysis

b Determined from ${ }^{29}$ Si MAS NMR as described in Refs. [20] and [29]

silanol groups of microspheres with $\mathrm{N}$-[3-(dimethylchlorosilyl)propyl]imidazole hydrochloride. A similar synthesis is described in Ref. [28]. The imidazole groups in microspheres were subjected to reaction with $n$-octyl iodide or methyl iodide to obtain ionic imidazolium iodide groups, Eq. 3. Characterization of functional microspheres is shown in Table 1. was determined using the Bradford method. Series of experiments were performed at $\mathrm{pH}$ 5.2, 7.4 and 9.2. PBS stabilized $\mathrm{pH}$ at 7.4, it is close to the isoelectric point of $\gamma$ globulins equal to $7.8[22,24]$. The protein solutions with $\mathrm{pH}$ 5.2 and 9.2, provided by phosphate and carbonate buffers, respectively, were used with purpose to check efficiency of
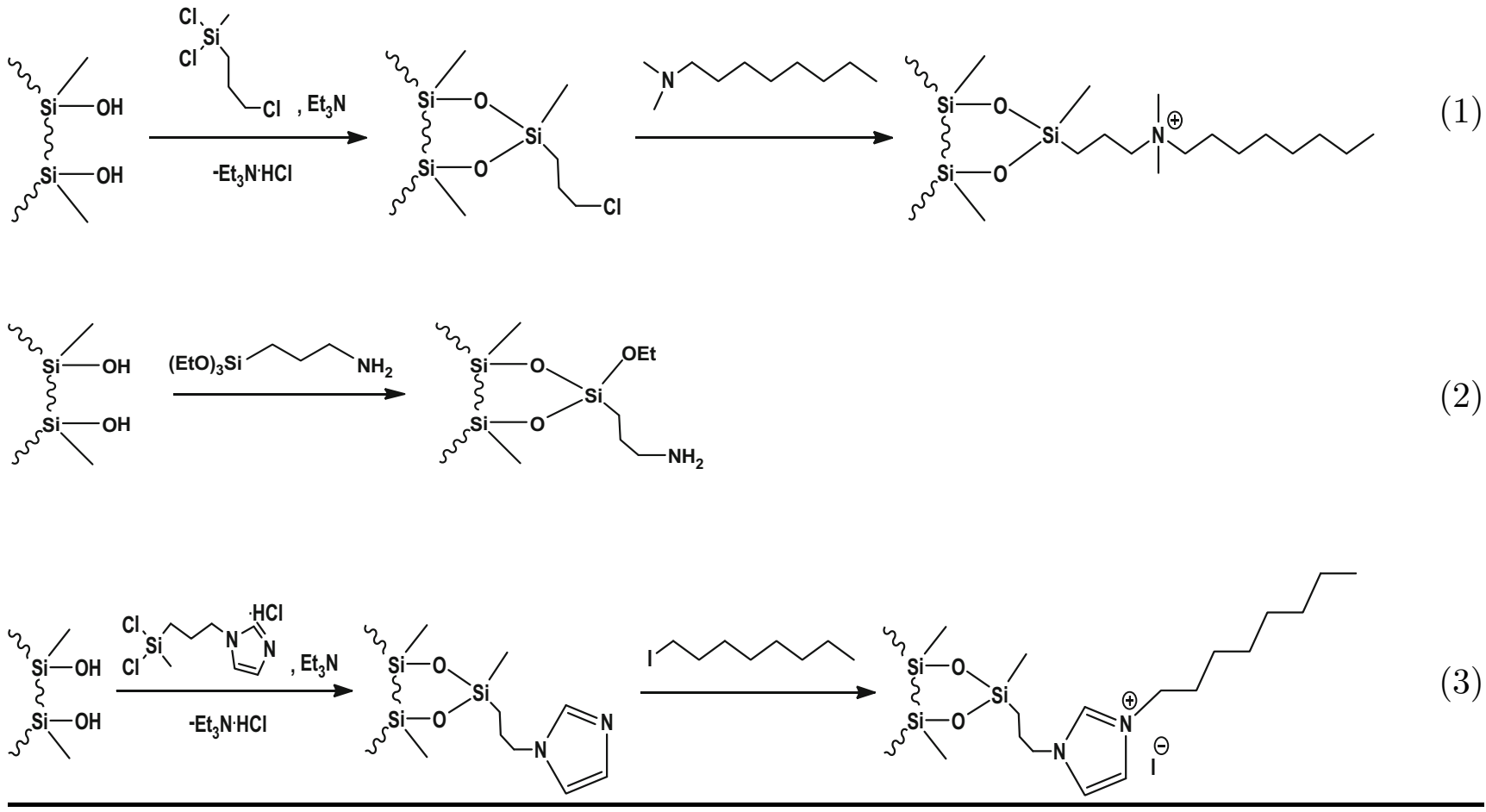

Carbofunctional silanes reacted not only with silanol groups on the surface of microspheres but also with those placed in the interior of particles [20]. Some fractions of $\mathrm{SiOH}$ and $\mathrm{SiH}$ groups were consumed by condensation reactions parallel to the silylation processes.

\subsection{Adsorption of $\gamma$-Globulins}

Adsorption of $\gamma$-globulins on the functionalized polysiloxane microspheres suspended in an aqueous protein solution adsorption below and above isoelectric point of $\gamma$-globulins. Adsorption isotherms for the functionalized microspheres determined at different $\mathrm{pH}$ are shown in Figs. 3, 4 and 5.

The isotherms are fairly well reproducible with surface concentration of protein approaching plateau, corresponding to saturation of the surface, for growing concentration of $\gamma$-globulin in solution. The surface concentration at saturation was used to calculate the percent of surface coverage, assuming that a monolayer is formed. These calculations were performed for number average molecular 


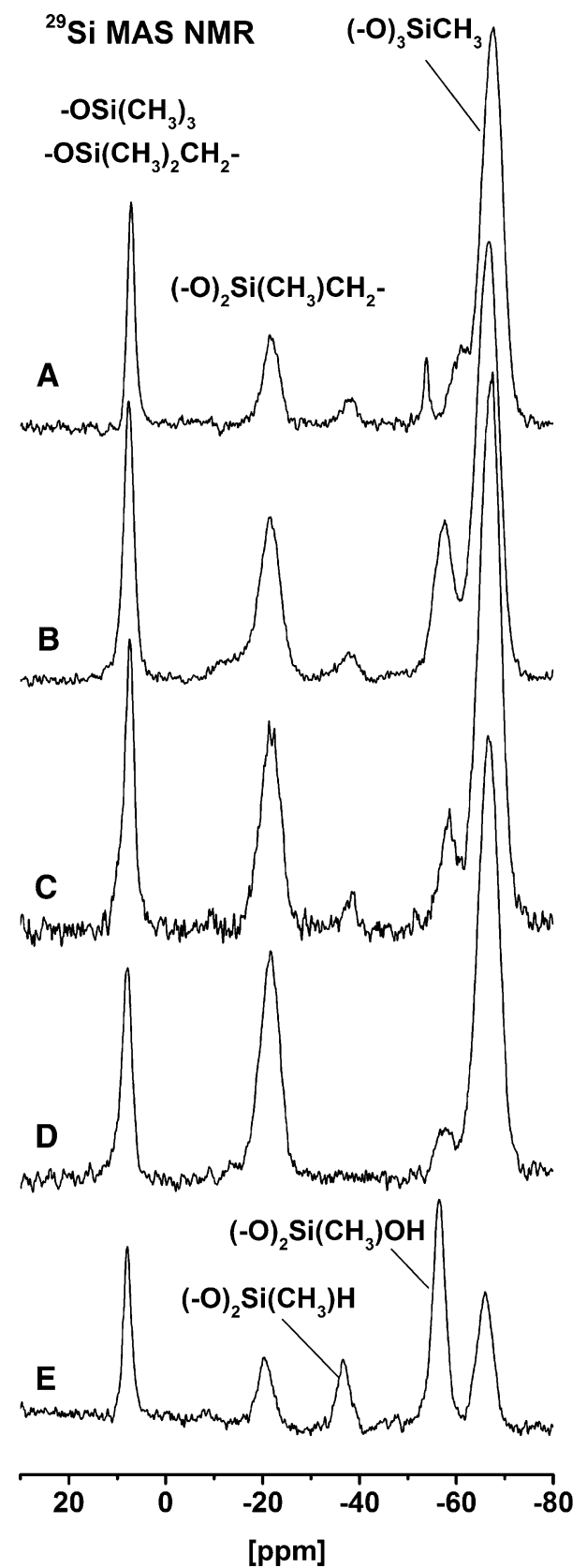

Fig. $1{ }^{29} \mathrm{Si}$ MAS NMR of microspheres functionalized by: $A$ 3aminopropyl, $B$ 3- $N$-imidazole-propyl, $C$ 3- $N(N-n$-octylimidazolio)propyl iodide, $D$ 3- $n$-octyldimethylammoniopropyl chloride, $E$ silanol groups (microspheres unfunctionalized)

weight of $\gamma$-globulins equal $160 \mathrm{kDa}$, the dimensions 23/2.5/2.5 $\mathrm{nm}$ and assuming their vertical orientation with contracted $\mathrm{F}(\mathrm{ab})$ fragment [25]. Data in Table 2 indicate that in some cases the degree of coverage exceeds $100 \%$, suggesting formation of a protein layer thicker than the monolayer.

Plots in Fig. 6a-c indicate that adsorption isotherms conform quite well to the Langmuir model, formulated for not specific interactions of protein with surfaces of microspheres.

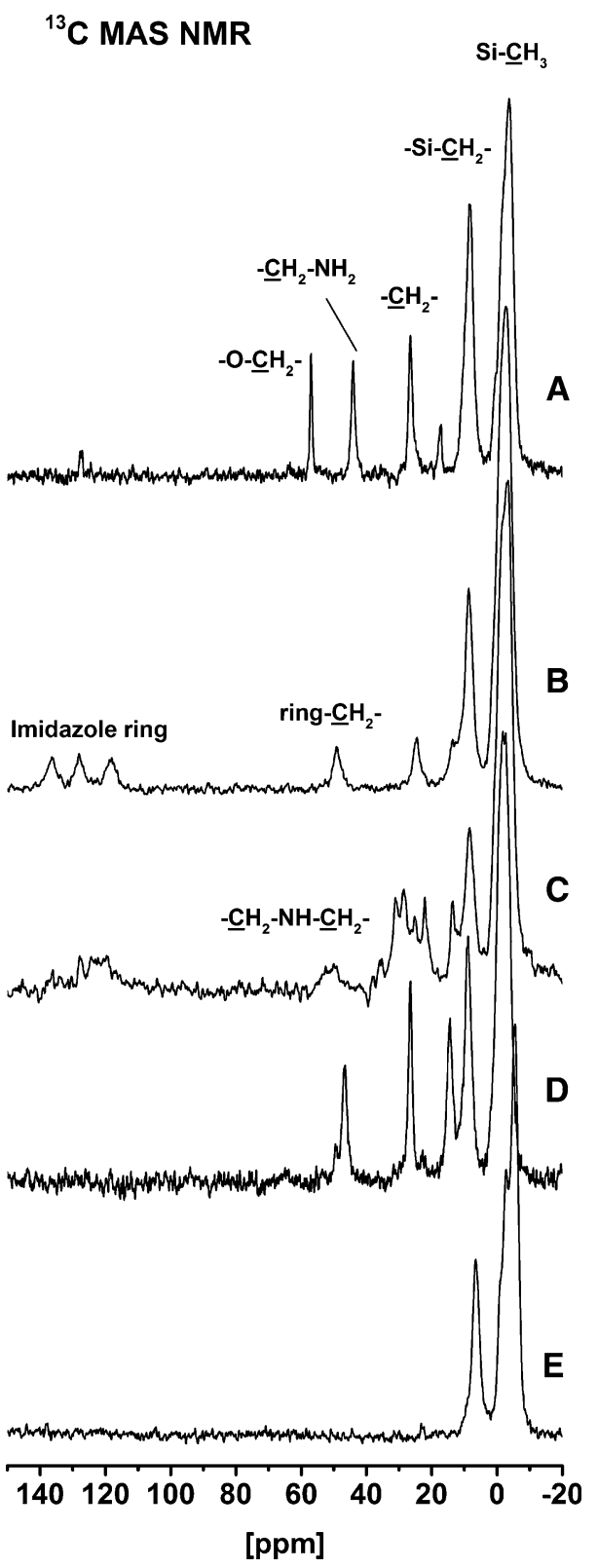

Fig. $2{ }^{13} \mathrm{C}$ MAS NMR of microspheres functionalized by: $A$ 3aminopropyl, $B$ 3- $N$-imidazole-propyl, $C$ 3- $N(N$-methylimidozolio)propyl iodide, $D$ 3-n-octyldimethylammoniopropyl chloride, $E$ silanol groups (microspheres unfunctionalized)

The adsorption isotherms determined at $\mathrm{pH} 7.4$ for functionalized microspheres were compared with those for not functionalized ones, being rich in $\mathrm{SiOH}$ groups (see Fig. 3 in which line $\mathrm{F}$ corresponds to adsorption onto not functionalized particles). All functionalized microspheres adsorbed $\gamma$-globulins more efficiently than those rich in $\mathrm{SiOH}$ groups. Thus, the performed functionalization did not provide material for applications when a low protein adsorption is required. Evidently, functionalization resulting in a lower content of silanol groups leads to decreased 


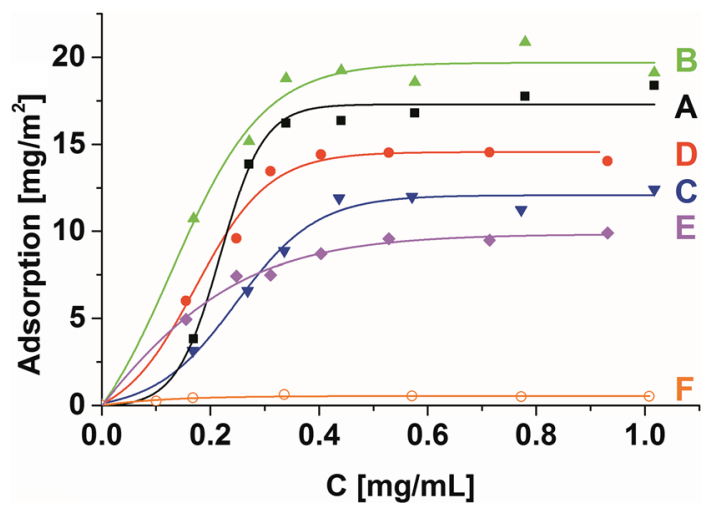

Fig. 3 Adsorption isotherms at $\mathrm{pH} 7.4$ of gamma globulins on microspheres functionalized by: A (square) 3-aminopropyl, $B$ (triangle ) 3- $N$-imidazole-propyl, $C$ (inverted triangle) 3-N(N-n-octylimidazoliopropyl iodide, $D$ (filled circle) 3-n-octyldimethylammoniopropyl chloride, $E$ (diamond) 3-N(N-methylimidazolio)propyl iodide, $F$ (open circle) silanol groups (microspheres unfunctionalized)

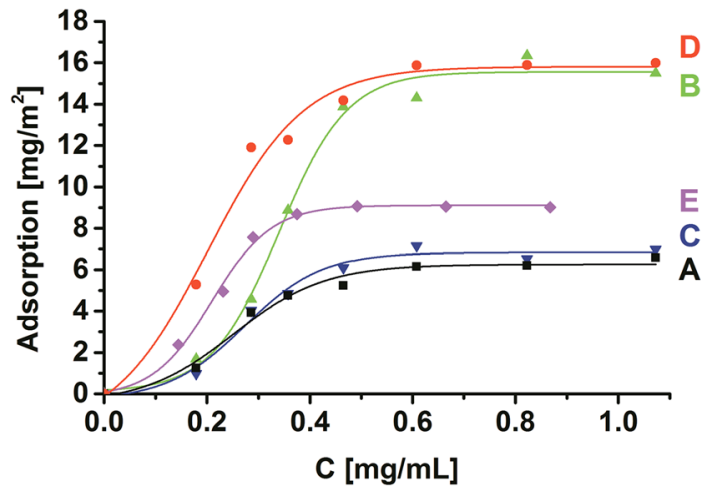

Fig. 4 Adsorption isotherms at $\mathrm{pH} 5.2$ of gamma globulins on microspheres functionalized by: $A$ (square) 3-aminopropyl, $B$ (triangle ) 3- $N$-imidazole-propyl, $C$ (inverted triangle) $3-N(N-n$-octylimidazoliopropyl iodide, $D$ (filled circle) 3-n-octyldimethylammoniopropyl chloride, $E$ (diamond) 3-N(N-methylimidazolio)propyl iodide

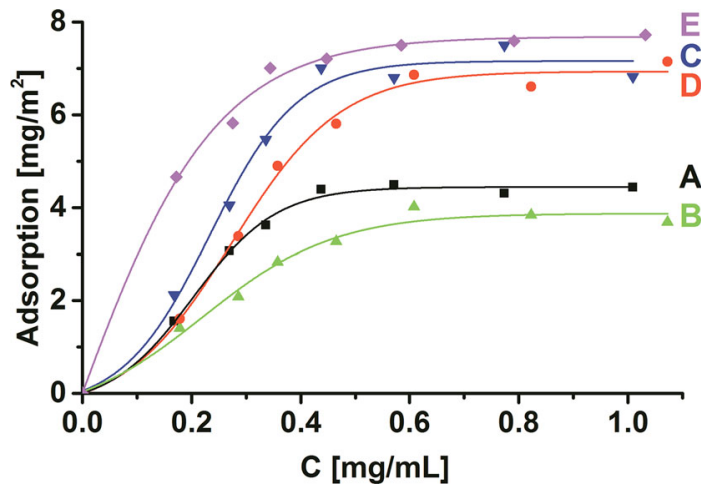

Fig. 5 Adsorption isotherms at $\mathrm{pH} 9.2$ of gamma globulins on microspheres functionalized by: A (square) 3-aminopropyl, $B$ (triangle ) 3- $N$-imidazole-propyl, $C$ (inverted triangle) 3- $N(N-n$-octylimidazoliopropyl iodide, $D$ (filled circle) 3-n-octyldimethylammoniopropyl chloride, E (diamond) 3-N(N-methylimidazolio)propyl iodide
Table 2 Gamma globulins adsorption on functionalized polysiloxanes microspheres

\begin{tabular}{|c|c|c|c|c|c|}
\hline \multirow[t]{2}{*}{ No } & \multirow[t]{2}{*}{ Functional group } & \multirow[t]{2}{*}{$\mathrm{pH}$} & \multicolumn{2}{|c|}{$\begin{array}{l}\text { Gamma globulin } \\
\text { adsorption }\end{array}$} & \multirow[t]{2}{*}{$\begin{array}{l}\% \text { of surface } \\
\text { coverage }\end{array}$} \\
\hline & & & $\begin{array}{l}10^{7} \\
\mathrm{~mol} / \mathrm{m}^{2}\end{array}$ & $\begin{array}{l}10^{8} \\
\mathrm{~mol} / \mathrm{g}\end{array}$ & \\
\hline 1 & $\mathrm{SiOH}$ (native) & 7.4 & 0.03 & 0.12 & 3 \\
\hline \multirow[t]{3}{*}{2} & \multirow[t]{3}{*}{$\mathrm{Si}\left(\mathrm{CH}_{2}\right)_{3} \mathrm{NH}_{2}$} & 7.4 & 1.02 & 2.95 & 124 \\
\hline & & 5.2 & 0.39 & 1.13 & 48 \\
\hline & & 9.2 & 0.27 & 0.78 & 33 \\
\hline \multirow[t]{3}{*}{3} & \multirow[t]{3}{*}{$\mathrm{Si}\left(\mathrm{CH}_{2}\right)_{3}-\mathrm{Im}$} & 7.4 & 1.21 & 2.92 & 147 \\
\hline & & 5.2 & 0.96 & 2.31 & 117 \\
\hline & & 9.2 & 0.23 & 0.56 & 28 \\
\hline \multirow[t]{3}{*}{4} & \multirow[t]{3}{*}{$\mathrm{Si}\left(\mathrm{CH}_{2}\right)_{3}-\mathrm{ImOct}^{+} \mathrm{I}^{-}$} & 7.4 & 0.74 & 1.78 & 90 \\
\hline & & 5.2 & 0.42 & 1.01 & 51 \\
\hline & & 9.2 & 0.44 & 1.06 & 53 \\
\hline \multirow[t]{3}{*}{5} & \multirow[t]{3}{*}{$\mathrm{Si}\left(\mathrm{CH}_{2}\right)_{3}-\mathrm{ImMe}^{+} \mathrm{I}^{-}$} & 7.4 & 0.60 & 1.45 & 73 \\
\hline & & 5.2 & 0.56 & 1.35 & 68 \\
\hline & & 9.2 & 0.48 & 1.58 & 58 \\
\hline \multirow[t]{2}{*}{6} & \multirow{2}{*}{$\begin{array}{l}\mathrm{Si}\left(\mathrm{CH}_{2}\right)_{3} \mathrm{~N}(\mathrm{Me})_{2} \\
\mathrm{Oct}^{+} \mathrm{Cl}^{-}\end{array}$} & 7.4 & 0.90 & 2.18 & 109 \\
\hline & & 9.2 & 0.43 & 1.04 & 52 \\
\hline
\end{tabular}

hydrophilicity of the surface and increased adsorption of $\gamma$ globulins. In some cases condensation of silanol groups additionally reduces their content. Substitution of $\mathrm{SiOH}$ groups by carbofunctional organic siloxy groups increases hydrophobicity of polysiloxanes which was confirmed by more efficient adsorption of hydrophobic dye Rose Bengal, a commonly used method for determination of hydrophobicity of surfaces of particles [30-33]. The adsorption of Rose Bengal on microspheres is displayed in Fig. 7 in which the partitioning quotient, it is the ratio of the amount of dye which was adsorbed to that remaining in the solution, as function of the total surface of microspheres is shown.

The carbofunctional microspheres subjected to the Rose Bengal test are much more hydrophobic than the unfunctionalized ones rich in $\mathrm{SiOH}$ microspheres, which do not adsorb the hydrophobic dye. Relatively high hydrophobicity of microspheres with the quaternary ammonium groups seems to be related to the presence of the long alkyl chains bonded to nitrogen atoms.

Adsorption of proteins on surface of functionalized polysiloxanes depends significantly on $\mathrm{pH}$ of protein solution. Similar observations were made earlier [17]. The influence of $\mathrm{pH}$ on protein affinity is shown in Fig. 8. Small changes of $\mathrm{pH}$ has only a limited influence on the protein conformation, but may have a significant impact on the net charge and hydrophilic-hydrophobic properties of proteins and of the surface.

For all investigated microspheres the largest adsorption of $\gamma$-globulins was observed at $\mathrm{pH} \mathrm{7.4,} \mathrm{closed} \mathrm{to} \mathrm{isoelecteric}$ 

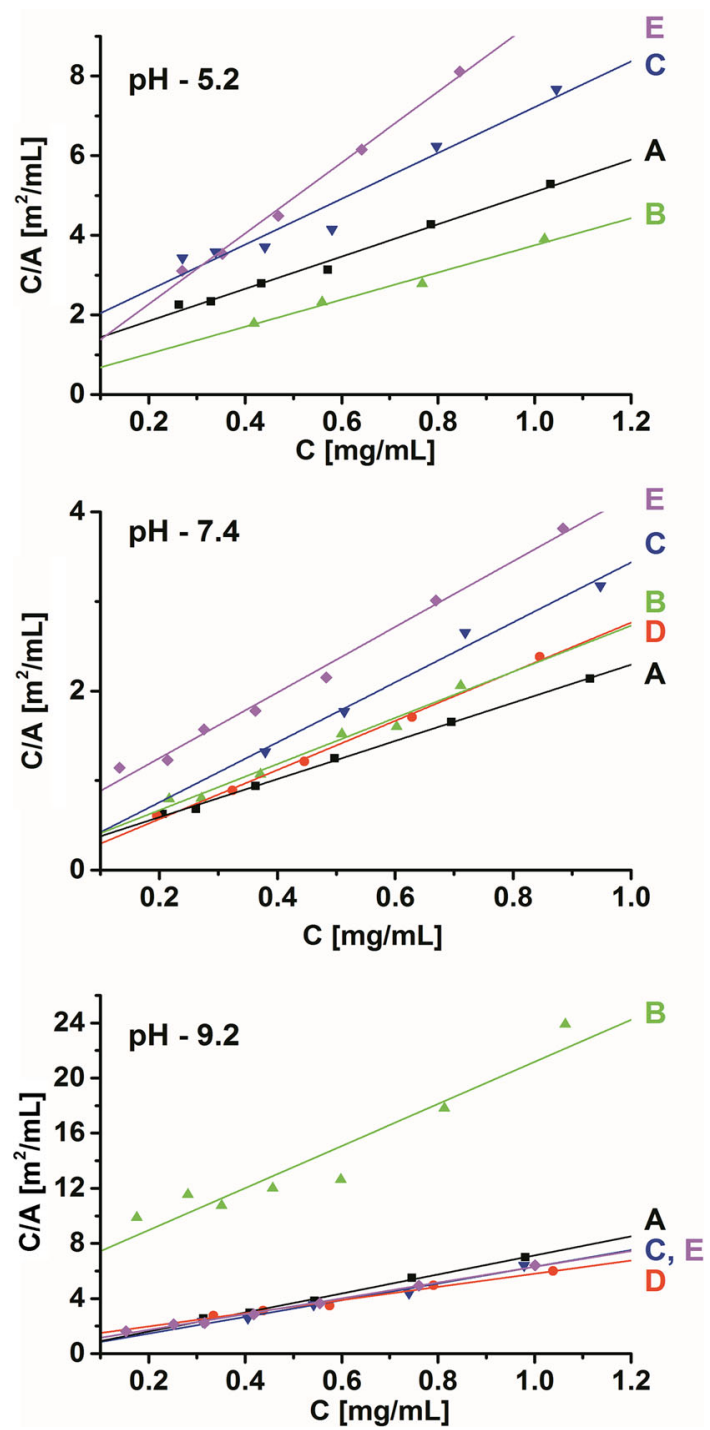

Fig. 6 Langmuir plots for the adsorption of gamma globulins on microspheres functionalized by: $A$ (square) 3 -aminopropyl, $B$ (triangle) 3- $N$-imidazolepropyl, $C$ (inverted triangle) 3- $N(N-n$-octylimidazoliopropyl iodide, $D$ (filled circle) 3-n-octyldimethylammoniopropyl chloride, $E$ (diamond) 3- $N(N$-methylimidazolio)propyl iodide, at $\mathrm{pH}$ a 7.4, b 5.2, c 9.2. The Langmuir analysis was performed using equation: $\mathrm{C} / \mathrm{A}=\mathrm{C} / \mathrm{a}+1 / \mathrm{ab}$ where $\mathrm{C}$ is concentration of globulins remaining in solution, $\mathrm{A}$ is surface concentration of globulins adsorbed, a is maximum surface concentration, $\mathrm{b}$ is adsorption-desorption equilibrium constant

point of $\gamma$-globulines (7.8). This means that when the total charge of protein macromolecules is close to zero the attractive hydrophobic forces prevail $[2,17]$. However, electrostatic interactions may play also an important role. At acidic conditions both, the surface of microspheres and $\gamma$-globulins are positively charged, which elicits repulsive forces. Consequently, a considerable decrease in the adsorption observed for microspheres functionalized with amine groups may be due to the contribution of these repulsive electrostatic forces involving some amine groups protonated at $\mathrm{pH}$ 5.2. A smaller, but noticeable decrease in the case of particles bearing

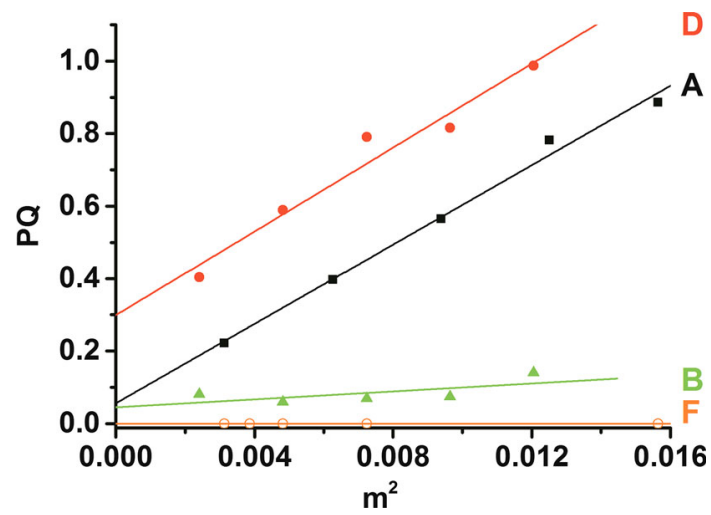

Fig. 7 Dependence of the partitioning quotient (PQ), i.e. mass of Rose Bengal adsorbed relatively to that remaining in the solution, on the total microspheres surface for microspheres functionalized by: A (square) 3-aminopropyl, B (triangle) 3- $N$-imidazole-propyl, $D$ (filled circle) 3-n-octyldimethylammoniopropyl chloride, $F$ (open circle) silanol groups (microspheres unfunctionalized)

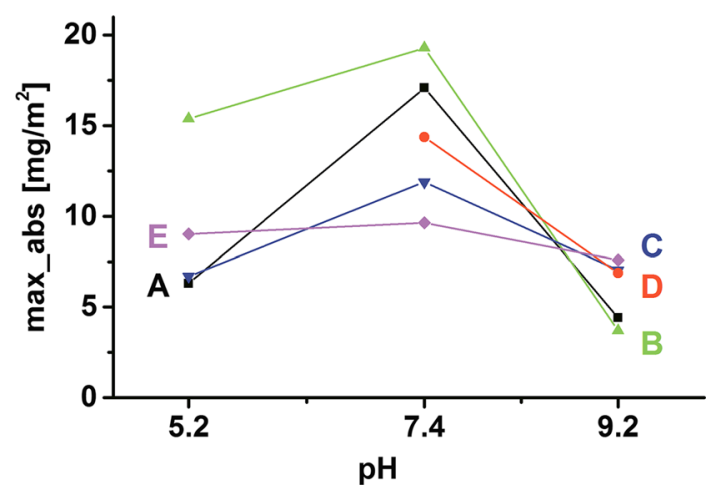

Fig. 8 Dependence of maximum globulins adsorption on $\mathrm{pH}$ of globulins solution for polysiloxane microspheres functionalized by: A (square) 3-aminopropyl, $B$ (triangle) 3- $N$-imidazolopropyl, $C$ (inverted triangle) 3- $N(N-n$-octylimidazoliopropyl iodide, $D$ (circle) 3-n-octyldimethylammoniopropyl chloride, $E$ (diamond) $3-N(N$-methylimidazolio)propyl iodide

imidazole groups may be due to lower basicity of imidazole in comparison with amines, resulting in a lower positive charge of the particles. $\gamma$-Globulines at $\mathrm{pH} 7.4$ showed lower affinity to positively loaded microspheres containing imidazolium ions than to the not charged particles with imidazole moieties. This relation was maintained in acidic medium, but became reversed at $\mathrm{pH}$ 9.2. Evidently, at basic conditions when protein macromolecules are negatively charged and therefore are attracted to the positively charged surfaces of microspheres bearing imidazolium cations. It is worth noting that imidazole is not charged at $\mathrm{pH} 9.2$.

\subsection{Conclusions}

The silylation of $\mathrm{SiOH}$ containing polysiloxane microspheres by organofunctional reactive silanes with functional groups: 3-aminopropyl, 3- $\mathrm{N}$-imidazole-propyl, 3-N(N-octylimidazo- 
lio)propyl iodide, 3-N(N-methylimidazolio)propyl iodide and 3-octyldimethylammoniopropyl chloride, increases the susceptibility of microspheres to protein adsorption.

Silylation of $\mathrm{SiOH}$ containing polysiloxane microspheres by using reactive silanes containing 3-aminopropyl, 3-Nimidazole-propyl and $n$-octyldimethylammoniopropyl chloride groups increases hydrophobicity of the particles.

The balance of hydrophilic-hydrophobic is the most important factor determining the ability of the investigated functionalized polysiloxane microspheres for the adsorption of $\gamma$-globulins. In the case of functionalized microspheres containing ionic groups the electrostatic interactions between proteins and surface of particles should be also taken into account.

The pristine polysiloxane microspheres prepared by the method described in Ref. [20], which are not functionalized, and therefore rich in $\mathrm{SiOH}$ groups, seems to be more suitable for some biomedical use when the adventitious adsorption of proteins should be eliminated. However, particles with imidazole may be interesting when $\mathrm{pH}$ sensitive adsorption is needed.

Acknowledgments Financial support from National Center of Sciences project NCN 2011/01/B/ST5/06662 is greatly appreciated.

Open Access This article is distributed under the terms of the Creative Commons Attribution License which permits any use, distribution, and reproduction in any medium, provided the original author(s) and the source are credited.

\section{References}

1. H. Chen, L. Yuan, W. Song, Z. Wu, D. Li, Prog. Polym. Sci. 33, 1059-1087 (2008)

2. D. Costa, P.A. Garrain, M. Baaden, J. Biomed. Mater. Res. 101A, 1210-1222 (2013)

3. R.G. Couston, D.A. Lamprou, S. Uddin, C.F. Van der Walle, Int. J. Pharm. 438, 71-80 (2012)

4. F. Meder, T. Daberkow, L. Treccani, M. Wilhelm, M. Schowalter, A. Rosenauer, L. Madler, K. Rezwan, Acta Biomater. 8, 1221-1229 (2012)

5. V. Bartzoka, M.R. McDermott, M.A. Brook, Adv. Mater. 11, 257-259 (1999)

6. M.S. Ehrenberg, A.E. Friedman, J.N. Filkenstein, G. Oberdörster, J.L. McGrath, Biomaterials 30, 603-610 (2009)

7. Z. Yang, Y. Chevolot, T. Gehin, V. Dugas, N. Xanthopoulos, V. Laporte, T. Delair, Y. Ataman-Önal, G. Choquet-Kastylevsky, E. Souteyrand, E. Laurenceau, Langmuir 29, 1498-1509 (2013)
8. A. Mashak, A. Rahimi, Iran. Polym. J. 18, 279-295 (2009)

9. Q. Tang, J.-R. Yu, L. Chen, J. Zhu, Z.-M. Hu, Curr. Appl. Phys. 11, 945-950 (2011)

10. H. Kanazawa, T. Okano, J. Chromatogr. A 1218, 8738-8747 (2011)

11. H. Dong, Y. Li, J. Li, G. Sheng, H. Chen, Ind. Eng. Chem. Res. 52, 9030-9037 (2013)

12. A. Durdureanu-Angheluta, M.-E. Ignat, S.S. Maier, L. Pricop, A. Coroaba, A. Fifere, M. Pinteala, A. Chiriac, Appl. Surf. Sci. 292, 898-905 (2014)

13. F. Abbasi, H. Mirzadeh, A.-A. Katbab, Polym. Int. 50, 1279-1287 (2001)

14. A.S. Mikhail, J.J. Ranger, L. Liu, R. Longenecker, D.B. Thompson, H.D. Sheardown, M.A. Brook, J. Biomater. Sci. Polym. Ed. 21, 821-842 (2010)

15. H. Chen, M.A. Brook, H. Sheardown, Biomaterials 25, 2273-2282 (2004)

16. J.-Y. Yoon, J.-H. Kim, V-S Kim. Colloid Surf. A Physicochem. Eng. Asp. 153, 413-419 (1999)

17. B. Liu, S. Cao, X. Deng, S. Li, R. Luo, Appl. Surf. Sci. 252, 7830-7836 (2006)

18. S. Cao, B. Liu, X. Deng, S. Li, Macromol. Biosci. 5, 669-676 (2005)

19. N. Nath, J. Hyun, H. Ma, A. Chilkoti, Surf. Sci. 570, 98-100 (2004)

20. W. Fortuniak, J. Chojnowski, S. Slomkowski, P. Pospiech, J. Kurjata, Polymer 54, 3156-3165 (2013)

21. U. Mizerska, W. Fortuniak, P. Pospiech, J. Chojnowski, S. Slomkowski, Polym. Adv. Technol. (2015). doi:10.1002/pat.3494

22. J. Buijs, J.W.Th. Lichtenbelt, W. Norde, J. Lyklema, Colloids Surf. B Biointerfaces 5, 11-23 (1995)

23. F. Kilar, I. Simon, S. Lakatos, F. Vonderviszt, G.A. Medgyesi, P. Zavodszky, Eur. J. Biochem. 147, 17-25 (1985)

24. M. Malmsten, J. Colloid Interface Sci. 166, 333-342 (1994)

25. M. Gosecka, S. Slomkowski, T. Basinska, Polym. Adv. Technol. 25, 1264-1272 (2014)

26. P. Bagchi, S.M. Birnbaum, J. Colloid Interface Sci. 83, 460-478 (1981)

27. V.A. Najjar, Adv. Enzymol. 41, 129-178 (1974)

28. W. Fortuniak, J. Chojnowski, Polym. Bull. 38, 371-378 (1997)

29. W. Fortuniak, S. Slomkowski, J. Chojnowski, J. Kurjata, A. Tracz, U. Mizerska, Colloid Polym. Sci. 291, 725-733 (2013)

30. M.-Ch. Jones, S.A. Jones, Y. Riffo-Vascuez, D. Spina, E. Hoffmann, A. Morgan, A. Patel, C. Page, B. Forbes, L.A. Dailey, J. Control. Release 183, 94-104 (2014)

31. S. Doktorovova, R. Shegokar, P. Martins-Lopes, A.M. Silva, C.M. Lopes, R.H. Müller, E.B. Souto, Eur. J. Pharm. Sci. 45, 606-612 (2012)

32. L. Francis, D. Meng, J. Knowles, T. Keshavarz, A.R. Boccaccini, I. Roy, Int. J. Mol. Sci. 12, 4294-4314 (2011)

33. F. Gao, Dyes Pigm. 52, 223-230 (2002) 